\title{
生存能の高い焼酎用酵母を用いた実験室規模での 返し仕込みによる蒸留残液からの焼酎製造
}

\author{
木田建次, 中川 優, 西迫博行, 森村 茂 \\ (熊本大学工学部物質生命化学科)
}

平成 8 年 11 月 14 日受理

\begin{abstract}
Production of Shochu from Post-Distillation Slurry in Laboratory-scale by a Newly Developed Recycling Process Using a High Viability Shochu Yeast.
\end{abstract}

Kenji Kida, Masaru Nakagawa, Hiroyuki Nishisako, Shigeru Morimura

(Department of Applied Chemistry and Biochemistry, Faculty of Enginieering, Kumamoto University, 2-39-1 Kurokami, Kumamoto-shi, Kumamoto-ken, 860)

A newly developed rice-shochu making process which reduces waste production and process cost has been studied. The low-waste process involved addition of the post-distillation slurry from the conventional method to moromi. In our previous report we bred shochu yeasts with high viability and selected from strain S 20 E 12 . In this report, firstly, by using strain S 20 E 12 we examined various conditions for preparing post-distillation slurry suitable for the newly developed recycling process of shochu making. It was found that suitable post-distillation slurry was derived from moromi with more than $30 \%$ koji ratio and 8 to 10 days of second-stage fermentation period in the conventional method. The activity of saccharifying enzymes remained stable and viable cell number was high, being $4.7 \times 10^{7}$ cells $/ \mathrm{m} \ell$ after vacuum distillation at -63 $\mathrm{cmHg}$ and $45^{\circ} \mathrm{C}$ for four hours. On the basis of these results, we studied optimum conditions for the newly developed recycling process. Moromi consisting of $138 \mathrm{~g}$ steamed rice and $175 \mathrm{~m} \boldsymbol{l}$ post-distillation slurry without addition of yeasts, rice-koji, and water, was fermented at $25^{\circ} \mathrm{C}$ for 4 different fermentation periods. Viable cell number was $3.7 \times 10^{8} \mathrm{cells} / \mathrm{m} \boldsymbol{l}$ on the 8 th day and $1.1 \times 10^{8}$ cells $/ \mathrm{m} \ell$ on the 15 th day. But there was a rapid increase of sulfur compounds and $\alpha$-amino compounds, especially in prolonged fermentation. Distillate of the moromi showed increase of acetaldehyde concentration and decrease of flavor compound with longer fer mentation time. The results suggest that distillation on moromi soon after completion of 8 day fermentation would make good quality shochu by the newly developed recycling process.

Key words：焼酎蒸留残液，返し仕込み，生存能の高い焼酎酵母

\section{緒言}

焼酎蒸留残液の海洋投棄が, 2001 年までに禁止さ れる。また焼酎の酒税がウィスキーに比べて低いのは ガット違反であると認定された1”。これらは焼酎業界 にとって死活問題であり, 製造コストの低減をも含め
た蒸留残液の効率的処理法の開発は緊急の問題である。 そこで,これらの問題点を解決するために返し仕込 みによる焼酎蒸留残液からの焼酎製造に関する検討を 行っている。返し仕込みによる焼酎製造法とは, 従来 法により焼酎製造を行った時に蒸留工程から排出され る蒸留残液を用いて焼酎を製造するものである。すな 
わち，従来法と返し仕込みを組み合わせたもので，返 し仕込みで焼酎を製造した時に初めて蒸留残液が排出 されることになるので，蒸留残液量は焼酎製造量に対 して半減することになる。しかし，この方法を実用化 するためには酒質が低下しない焼酎を製造しなければ ならないことから, 前報りにおいて生存能の高い焼酎 酵母の育種を試みた。その結果, 自己消化法により取 得したエ夕ノール耐性株は, 多くの酵母において野生 型株よりも生存能が向上することが分かった。そして, この生存能の向上した酵母の中から, 官能的にも優れ ていた S 20 E 12 株を最優秀株として選抜した。

本報では, 選抜した S 20 E 12 株を用いて実験室規 模での返し仕込みによる焼酎製造に関する研究を, (1) 従来仕込み条件の返し仕込みへの影響, (2)減圧蒸留中 の醪成分, 生菌数及び酵素活性の変化, (3)実験室規模 での返し仕込みによる焼酎製造条件の検討, および(4) 焼酎蒸留残液の冷却時間の影響の手順で行い, 実用化 のための基礎デー夕の取得を試みた。その結果, 実験 室規模で返し仕込みによる米焼酎製造技術を確立する ことができたので，報告する。

\section{実 験 方 法}

\section{1. 使用菌株}

官能試験に於て評価が高く, かつ生存能の高いこと から最優秀株として選抜されたエタノール耐性株 S 20 E 12 を用いた ${ }^{2)}$ 。

\section{2. 使用培地および菌株の保存方法}

$2 \% \mathrm{YPD}$ 斜面培地および $11 \%$ エ ノール含有 $2 \%$ YPD 斜面培地の調製は, 前報 ${ }^{2} に$ 記載した方法に
より行った。また, エ夕ノール含有斜面培地での保存 も前報に従って行った。

\section{3. 従来法による小スケール $(200 \mathrm{~m} \ell)$ および}

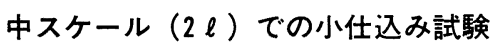

前報 ${ }^{21}$ に記載した方法に準じて行った。但し，小ス ケールにおいては麴歩合が 10〜 40\%の条件で行った ので, その時の仕込み割合を Table 1 に示した。

4. 小スケール (約 $100 \mathrm{~m} \ell)$ および中スケール

\section{$(2 \ell)$ での返し仕込み試験}

前報2゙に記載した方法で酵母を培養した後, 酵母量 が $2.0 \times 10^{9}$ 個になるように集菌, 洗浄後, この洗浄

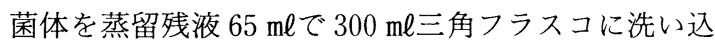
んだ。これに蒸米 $51 \mathrm{~g}$ (掛米 $39.2 \mathrm{~g}$ ) を加え, 三角 フラスコの上部をサランラップで覆った後, $25^{\circ} \mathrm{C} て ゙$ 静 置培養した。仕込み期間中は 1 日 1 回三角フラスコを 手で振り混ぜた。但し, この時使用した蒸留残液は上 述した麴歩合の異なる最終慗 $200 \mathrm{~m} \ell$ を後述する減圧蒸 留の方法に準じて行ったものであるが，この時の操作 圧だけはー73 cmHgであった。

中スケールでの返し仕込み試験は，䴯歩合 $33 \%$ の 二次最終鉁 $1,600 \mathrm{~m} \ell$ を後述する減圧蒸留法で蒸留した 残液を用いて行った。本試験では酒母や麴を一切加え ることなく,ただ $2 \ell$ の角フラスコに蒸留残液の $900 \mathrm{~m} \ell$ と蒸米 $710 \mathrm{~g}$ （掛米 $546 \mathrm{~g}$ ）だけを加え, その後 三角フラスコのロをサランラップで覆った後, 小スケ ールと同じ方法にて行った。

\section{5. 減圧蒸留試験}

$2 \ell$ スケールで小仕込み試験をした二次最終樛を減 圧蒸留試験に供した。Fig.1にその減圧蒸留装置を示

Table 1 Proportions of materials for laboratory-scale shochu making by the conventional method.

\begin{tabular}{c|c|c|c|c|c|c}
\hline \multirow{2}{*}{ Koji ratio } & \multicolumn{3}{|c|}{$\begin{array}{c}\text { First-stage moromi } \\
\text { fermentation }\end{array}$} & \multicolumn{3}{c}{$\begin{array}{c}\text { Second-stage moromi } \\
\text { fermentation }\end{array}$} \\
\cline { 2 - 7 } & koji rice & koji & water & rice & $\begin{array}{c}\text { steamed } \\
\text { rice }\end{array}$ & water \\
\hline $40 \%$ & $24.5 \mathrm{~g}$ & $27.3 \mathrm{~g}$ & $29.4 \mathrm{ml}$ & $61.2 \mathrm{~g}$ & $79.6 \mathrm{~g}$ & $112.0 \mathrm{ml}$ \\
$30 \%$ & $19.8 \mathrm{~g}$ & $22.1 \mathrm{~g}$ & $23.8 \mathrm{ml}$ & $65.9 \mathrm{~g}$ & $85.7 \mathrm{~g}$ & $117.6 \mathrm{ml}$ \\
$20 \%$ & $14.3 \mathrm{~g}$ & $15.9 \mathrm{~g}$ & $17.2 \mathrm{ml}$ & $71.4 \mathrm{~g}$ & $92.8 \mathrm{~g}$ & $124.2 \mathrm{ml}$ \\
$10 \%$ & $7.8 \mathrm{~g}$ & $8.7 \mathrm{~g}$ & $9.4 \mathrm{ml}$ & $77.9 \mathrm{~g}$ & $101.3 \mathrm{~g}$ & $132.0 \mathrm{ml}$ \\
\hline
\end{tabular}

Total amounts of rice and water were $85.7 \mathrm{~g}$ and $141.4 \mathrm{ml}$, respectively, and the ratio of water to rice was $165 \%$. 


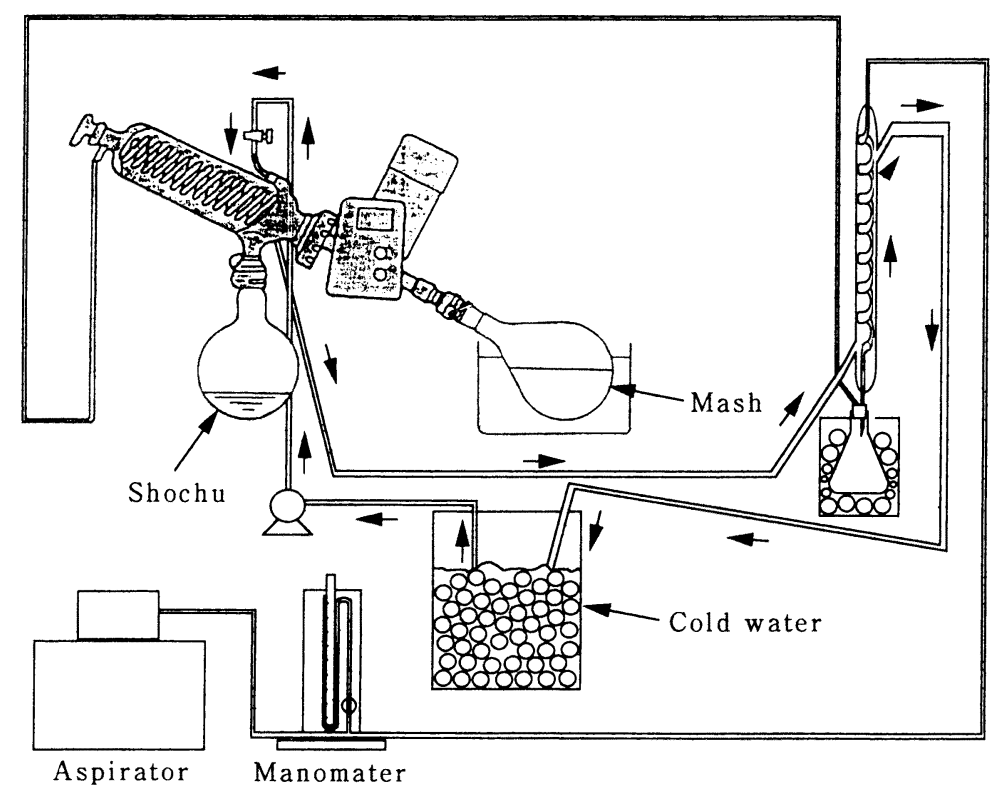

Fig.1 Diagram of laboratory-equipment for vacuum distillation.

した。 $2 \ell$ のナス型フラスコに二次最終酤 $1,600 \mathrm{~m} \ell$ を 入れロータリーエバポレーター(S 003, 東京理科機械, 東京）に装着した後, 温度 $45^{\circ} \mathrm{C}$, 操作圧 $-63 \mathrm{cmHg}$ の条件で行い，醪の $40 \%$ に相当する留出液を得た時 点で蒸留を終了した。蒸留期間中エバポレーター内の 蛇管及び留出側に設けたリービッヒ冷却管には $4{ }^{\circ} \mathrm{C} の$ 冷却水を常時通水した。但し, 二次最終糝 $250 \mathrm{~m} \ell も し$ くは $700 \mathrm{~m} \ell$ 蒸留するときは 1 と のナス型フラスコを 用いた。

\section{6. 分析方法}

分析用サンプルの調製，総菌数と生菌数の測定，生 成エタノール濃度, $\alpha-$ アミノ態窒素濃度, 硫黄濃度, クエン酸濃度の分析，そしてグルコアミラーゼ活性， 耐酸性 $\alpha-$ アミラーゼ活性の測定は前報 ${ }^{2}$ の方法に従っ て行った。

製品中の低沸点香気成分の分析は前報の方法に従つ て行った。また，中高沸点香気成分は，ジエチルエー テルで 1 回抽出した後，ガスクロマトグラフィーによ り分析した。すなわち, $300 \mathrm{~m} \ell$ 分液ロートに製品 $50 \mathrm{~m} \ell$, ジエチルエーテル $50 \mathrm{~m} \ell$, 飽和食塩水 $50 \mathrm{~m} \ell$ そて 400 $\mathrm{ppm}$ セチルアルコール（内部標準液） $1 \mathrm{~m} \ell$ を加え, 10 分間振とうすることにより抽出した後, 直接注入 法による FID ガスクロマトグラフィーにより定量し
た。カラムはエタノール測定用カラムを用い, 温度プ ログラムは $90 \sim 250^{\circ} \mathrm{C}$ ま゙昇温速度 $3^{\circ} \mathrm{C} / \mathrm{min}, 250^{\circ} \mathrm{C}$ で 7 分間保持するものとした。注入口温度は $250^{\circ} \mathrm{C}$, FID 温度は $250^{\circ} \mathrm{C}$ ，スプリット比は $1 / 50$ とした。

\section{実験結果および考察}

\section{1. 従来仕込み条件の返し仕込みへの影響}

返し仕込みで使用する蒸留残液に醪臭の原因となる アミノ態窒素や硫黄分が多く含まれると，得られる製 品の酒質も低下するものと考えられたので, 従来法の 仕込み日数と醪中の成分変化について調べた。また， 三枝らは3従来法による焼酎製造において麴歩合が低 くなるほど低級脂肪酸エステルの生成濃度が高くなる と報告している。しかし，麴歩合が低くなると糖化酵 素活性も低下寸るものと思われたので，返し仕込みの 発酵速度に及ぼす従来法の麴歩合の影響を調べた。

（1）二次仕込み日数の影響

アミノ態窒素や硫黄分からは酒質にとって好ましく ない成分が生成されると考えられるが，前報 ${ }^{2}$ で発酵 経過とともにまず原料由来のアミノ態窒素や硫黄分が 醪中に増加することを報告した。ここでは発酵後期に おいて菌体の死滅に伴いアミノ態窒素や硫黄分がさら に増加するかを調べた。 
麴歩合 $33 \%$ で二次仕込み $(2 \ell$ スケール) を 8 日間, 10 日間，12 日間，15日間行い，この時得たそれぞれ の最終醪を分析することにより，至適な仕込み日数の 検討を行った。Table 2 に示したように，9 日間以降 生成エタノール濃度は変化していないことから, 前 報 ${ }^{2}$ 同様 9 日目に既に発酵は終了しているものと思わ れた。そのために生存率は 9 日目から大幅に低下した が，16 日目においても5\%と酵母はなお生存しており， その時の生菌数は $1.3 \times 10^{7}$ cells/meであった。しかし, 死滅が始まった直後ほとんど変化しなかったアミノ態 窒素や硫黄分も死滅開始 4 日後の 13 日目に 10〜20\% 増加した。このことは酵母が死滅した後, 数日後に自 己消化が起こり, その結果酵母由来のアミノ態窒素や 硫黄分が増加したと言える。一方，耐酸性 $\alpha^{-}$アミラ 一ゼ活性やグルコアミラーゼ活性はほとんど変わらな いが，13 日目に約 10\%低下していた。これは，自己 消化により漏出したプロテアーゼにより糖化酵素が加 水分解され ${ }^{4)}$, 活性が低下したものと考えられた。

これら 4 種類の最終醪 $700 \mathrm{~m} \ell$ を蒸留し, 得られた製 品の低沸点および中高沸点香気成分の分析を行った。 Table 3 に示したように, 吟醸香の一つである酢酸 イソアミルは吟醇酒においても最大で約 $15 \mathrm{mg} / \mathrm{l}$ と 言われているが5)，製品に約 $7 \mathrm{mg} / \ell$ も含まれていた。 しかし, 香気成分であるエステル類や高級アルコール 類は仕込み日数が長くなるほど減少する傾向を示した。 一方，ガス臭の原因となるアセトアルデヒドは仕込み 日数が長くなるほど増加した。一般に減圧蒸留ででき

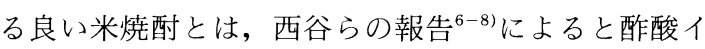
ソアミルや酶酸 $\beta$-フェネチル, カプロン酸エチル等
のエステル類や高級アルコール類が多く，且つアセト アルデヒドが少ないものと考えられる。従って，S 20 E 12 株による従来法での焼酎製造においては仕込み 日数が長くならない方が好ましいと言える。

発酵期間中の原料由来のアミノ態窒素や硫黄分の増 加は，抑えることはできないが，酵母死滅後自己消化 により増加する窒素や硫黄分は, 二次仕込み日数を発 酵が終了する 8〜10日とすることにより抑制できるこ とがわかった。また，返し仕込みでの酒母添加を無く すためにも二次仕込み日数は, 発酵が終了する 8 も くは 9 日間とすることが望ましいと言える。さらに， 酒質面からも従来法の仕込み日数は 8～10 日間とすべ きである。

\section{（2）麴歩合の影響}

麴歩合 10 40\%で従来法による小仕込み試験（200 ml）をそれぞれ 2 回行った。1 回目, 2 回目での経日 変化にほとんど差はなかったので, Fig. 2 に二次仕込 みにおける醪減少量の平均值を示した。麳歩合 $10 \%$ では発酵速度が若干低下したが，20\%以上でほとんど 変わらなかった。しかし，仕込み 10 日間のエ夕ノー ル濃度は䴯歩合 $20 \%$ では， $16.9 \% \mathrm{v} / \mathrm{v}$ と, 䴯歩合 $30 \%$ 以上に比べて約 $1.7 \% \mathrm{v} / \mathrm{v}$ 低かった。この原因と しては, 各麴歩合での 10 日目グルコアミラーゼ活性 $0.87,1.07,1.39$ および $1.46 \mathrm{U} / \mathrm{m} \ell$ から, 䴳歩合を 下げることにより醪中の糖化酵素活性が低下したため と考えられる。

\section{（3） 小スケール $(100 \mathrm{~m} \ell)$ での返し仕込み}

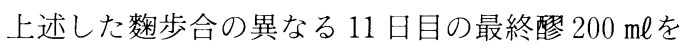
実験方法に記載した条件で蒸留し，得られた蒸留残液

Table 2 Effect of fermentation times in the second-stage moromi mash on viability and autolysis of the yeast.

\begin{tabular}{l|c|c|c|c}
\hline \hline \multirow{2}{*}{ Moromi mash } & \multicolumn{4}{|c}{ Second-stage fermentation } \\
\cline { 2 - 5 } & after $8-\mathrm{d}$ & after 10-d & after 12-d & after 15-d \\
\hline Total cell number (cells/ml) & $2.7 \times 10^{8}$ & $3.4 \times 10^{8}$ & $2.8 \times 10^{8}$ & $2.6 \times 10^{8}$ \\
Viable cell number (cells/ml) & $1.4 \times 10^{8}$ & $4.3 \times 10^{7}$ & $1.7 \times 10^{7}$ & $1.3 \times 10^{7}$ \\
Viability (\%) & 51.9 & 12.6 & 6.1 & 5.0 \\
Acid stable $\boldsymbol{\alpha}$-amylase $(\mathrm{U} / \mathrm{ml})$ & 8.4 & 8.0 & 7.3 & 7.2 \\
Glucoamylase $(\mathrm{U} / \mathrm{ml})$ & 3.5 & 3.4 & 3.1 & 3.1 \\
Sulfur compound-S $(\mathrm{mg} / l)$ & 202.5 & 201.8 & 218.4 & 215.5 \\
$\boldsymbol{\alpha}$-Amino nitrogen $(\mathrm{mg} / \mathrm{l})$ & 992.5 & $1,005.7$ & $1,220.7$ & $1,22.7$ \\
Ethanol concentration $(\mathrm{v} / \mathrm{v} \%)$ & 19.5 & 19.7 & 19.8 & 19.8 \\
\hline
\end{tabular}

The second-stage moromi mash consisting of $355 \mathrm{ml}$ of the first-stage moromi mash with $33 \%$ koji ratio, $966 \mathrm{ml}$ of water and $698 \mathrm{~g}$ of steamed rice was fermented at $25^{\circ} \mathrm{C}$ for 8 , 10,12 or 15 days. 
Table 3 Analysis of flavor compounds in shochu made by the conventional method.

\begin{tabular}{|c|c|c|c|c|}
\hline \multirow{2}{*}{ Flavor compounds } & \multicolumn{4}{|c|}{ Second-stage fermentation } \\
\hline & after 8 -d & after $10 \cdot d$ & after $12-\mathrm{d}$ & after $15-d$ \\
\hline Acetaldehyde & 4.2 & 4.9 & 7.4 & 8.0 \\
\hline Ethyl acetate & 69.6 & 52.6 & 48.3 & 40.9 \\
\hline n'Propyl alcohol & 168.1 & 106.5 & 83.8 & 96.1 \\
\hline Isobutyl alcohol & 186.5 & 185.2 & 176.2 & 142.4 \\
\hline Isoamyl acetate & 7.2 & 7.3 & 2.7 & 4.8 \\
\hline $\begin{array}{l}\text { Active amyl alcohol } \\
\text { Isoamyl alcohol }\end{array}$ & 412.7 & 426.6 & 279.4 & 305.5 \\
\hline$\beta \cdot$ Phenetyl alcohol & 26.9 & 29.5 & 22.6 & 24.1 \\
\hline Ethl n-caprylate & 1.6 & 1.1 & 1.0 & 0.8 \\
\hline$\beta \cdot$ Phenetyl acetate & 2.0 & 1.7 & 1.5 & 1.4 \\
\hline Ethyl laurate & 0.2 & 0.1 & 0.2 & 0.1 \\
\hline Ethyl myristate & 0.5 & 0.4 & 0.3 & 0.3 \\
\hline Ethyl linoleate & 0.6 & 0.7 & 0.5 & 0.6 \\
\hline Ethyl oleate & N.D. & N.D. & N.D. & N.D. \\
\hline Ethyl stearate & N.D. & N.D. & N.D. & N.D. \\
\hline $\begin{array}{l}\text { Acidity } \\
\mathrm{pH}\end{array}$ & - & $\begin{array}{l}0.7 \\
4.7 \\
\end{array}$ & - & $\begin{array}{l}0.7 \\
4.6\end{array}$ \\
\hline
\end{tabular}

Four kinds of the second-stage moromi mash $(1,600 \mathrm{ml}$ each) made in Table 2 were vaccum-distilled. The distillate served as a shochu sample for the flavor analysis.

を用いて返し仕込み実験を行った。Fig.3に示したよ うに，数歩合 $10 \%$ では，仕込み 11 日目に扔いても醪 減少量がデンプン価から算出した理論量 $(15.5 \mathrm{~g})$ の 約 70\%であったが,䴹歩合 $20 \%$ でほぼ理論量に達した。 麴歩合 $30 \%$ 以上では，仕込み 9 あるいは 10 日目で醪 減少量は理論量に達していた。一方，仕込み 11 日目 の生成エタノール濃度は䴯歩合 $20 \%$ 以上で約 $18 \% \mathrm{v} /$ vに達していた。しかし，麳歩 $10 \%$ や，20\%では 返し仕込み初期では醪粘度が高く, $2 \sim 3$ 日後に液化 が進みやっと粘度が低下した。このような場合（䴹歩 合 $20 \%$ ）においても，返し仕込み開始時点で麴を $10 \%$ 添加することにより液化は進行し, 発酵は無添加 の時よりも1〜2 日間短縮され，10日目に終了した。

以上, 返し仕込みの発酵速度および開始時の粘度か ら, 従来法での麴歩合を $30 \%$ 以上にすることが望ま しい。また, 球磨地区の多くの醸造場での麴歩合は 33\%であることから，以後の試験では従来法の麴歩合 を33\%とした。

\section{2. 隇圧蒸留時の生菌数, 酢素活性等の変化}

上述した蒸留残液は 30 分以内の減圧蒸留により得
られたものであるが，この蒸留残液を用いた返し仕込 みでは, 特に酒母や麴の添加が必要ないものと思われ た。しかし, 現場での減圧蒸留は, 操作圧 $-70 \mathrm{cmHg}$, 温度 $30^{\circ} \mathrm{C}$ (初発) $\rightarrow 45^{\circ} \mathrm{C}$ (最終) の条件で $4 \sim 5$ 時間 かけて行われていることから, 実験室規模においても 4 時間かけて蒸留を行い, その間で酵素活性や生存率 の変化を調べる必要があると考えられた。

そこで, 試行錯誤により 4 時間かけて蒸留できる条 件を検討し，その結果に基づき実験方法に記載した方 法を採用した。Fig.4は，䴳歩合 $33 \%$ 二次 9 日目 の最終醪 $1,600 \mathrm{~m} \ell$ を蒸留し, その時の生菌数, 酵素活 性及び硫黄濃度の経時変化を示している。Fig.4一A は，1時間毎に常圧に戻しサンプリングし，分析した 時のそれぞれの值を示している。酵素活性や硫黄濃度 が増加している理由は, 上述したようにナス型フラス コ中の液量隇少によるものである。そこで, 液中のク エン酸濃度から液の減少, 即ち濃縮率を算出し換算し た值を Fig.4-B に示した。グルコアミラーゼ活性や 耐酸性 $\alpha$-アミラーゼ活性は, 蒸留開始 1 時間後に増 加しているが，その後一定した。糖化酵素の活性は蒸 


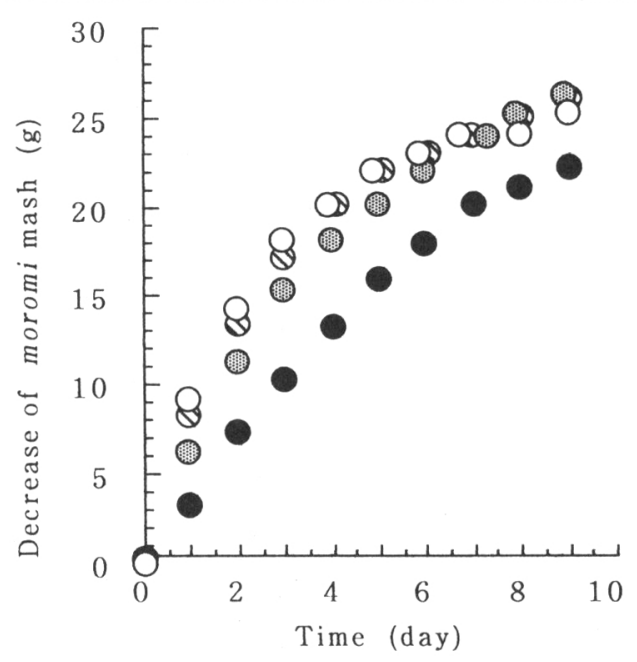

Fig.2 Effect of koji ratios on fermentation rates of the second-stage moromi mash (niji-shikomi) in the conventional method.

These tests were carried out parallel at each condition, and theoretical amount of moromi mash decrease was $26 \mathrm{~g}$. The concentration of ethanol produced at a various ratio of $k o j i \quad 40 \%$

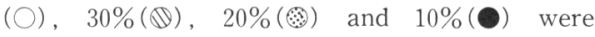
$18.7,18.6,16.9$ and $15.2 \%(\mathrm{v} / \mathrm{v})$, respectively.

留により増加し, 従来法の小仕込み試験において低下 することから ${ }^{2)}$ ，るエ夕ノール濃度以上で阻害され るものと推察された。しかし, この条件下での蒸留に おいては酵素活性は低下しないことが分かった。また, 蒸留に供した樛は 9 日目のものであり, その時の生存 率は $55.1 \%$ であった。4 時間の減圧蒸留により約 $35 \%$ 死滅したが, 生菌数は $4.7 \times 10^{7}$ cells/meであった。 また, 蒸留液中の硫黄濃度がほとんど増加していない ことから死滅しても自己消化していないものと考えら れた。

以上の結果から, 従来法の蒸留工程から排出される 蒸留残液は, 一次醪㧍よび汲水として返し仕込みで利 用できるものと期待された。

\section{3. 酒母および檞無添加での返し仕込みによる 焼酎製造}

現在, 球磨地区での銳造場における一次仕込みおよ び二次仕込み 1 日目の生菌数は, 我々が行った調查で は平均それぞれ $7.5 \times 10^{5}, 1 \sim 2 \times 10^{7}$ cells/mとであった。 従って, 上述結果から蒸留残液にただ蒸米だけを加え るだけで焼酎製造が可能と考えられた。

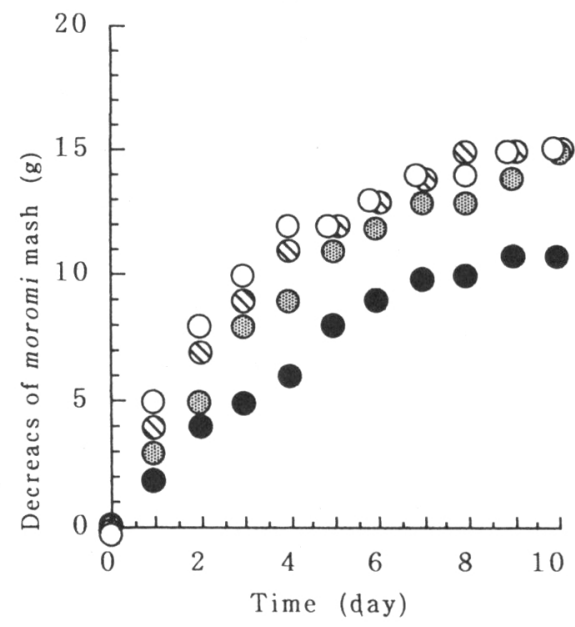

Fig.3 Effect of koji ratios used in moromi mash of the conventional method on moromi fermentation rates of the newly developed recycling process (kaeshi-jikomi) .

Post-distillation slurry was derived from distillation of the second-stage moromi mash prepared with various koji ratios shown in Fig.2. The theoretical amount of moromi mash decreace was $15 \mathrm{~g}$. Koji ratio applied in the conventional process: $\bigcirc, 40 \% ; \mathbb{1}, 30 \%$; 3. $20 \% ;-10 \%$. Concentration of ethanol after 10 -d were $17.8,18.4,17.9$ and $16.0 \%$ $(\mathrm{v} / \mathrm{v})$, respectively.

そこで, 棦歩合 $33 \%$ 二次仕込み 9 日目の最終醪 $1,600 \mathrm{~m} \ell$ を減圧蒸留し, 得られた蒸留残液を用いて酒 母及び䴹を添加することなく返し仕込み試験を行った。 Fig.5 に示したように,麳減少量は時間とともに增加 し, 8 日目以降ほ湾一定した。そこで, 返し仕込みを 9 日間で終了し, 醪の分析を行った。エタノールおよ び生菌数, 生存率はそれぞれ $18.3 \% \mathrm{v} / \mathrm{v}, 3.7 \times 10^{8}$

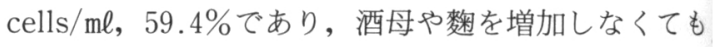
問題なく発酵できることが分かった。しかし, 生存率 は返し仕込みにおいて最大でも約 70\%であった。こ れは, 生菌数から判断して蒸留残液中の死滅酵母が総 菌数として加算されたためと考えられる。発酵時間中 の顕微鏡観察において雑菌污染は全く認められなかっ たが，有機酸を分析すると Fig.5 に示したような乳 酸やコハク酸, マロン酸, 酢酸が生成されており, そ 

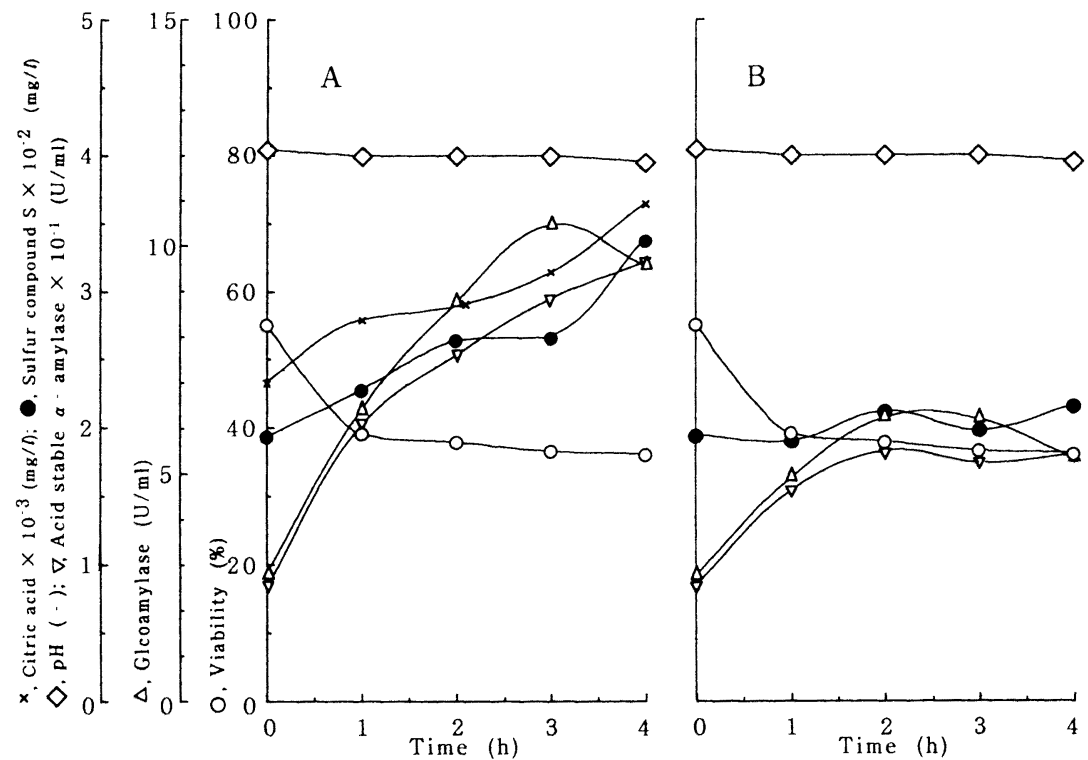

Fig.4 Changes in viability, saccharifying enzyme activites, pHs, sulfur compound-S and citric acid concentrations in the postdistillation slurry during vacuum-distillation.

The 9 th day moromi of the second-stage moromi mash with $33 \%$ koji ratio $(1,600$ $\mathrm{m} \ell$ ) was vacuum-distilled at $-63 \mathrm{cmHg}$ and $45^{\circ} \mathrm{C}$.

A : measured values. During distillation, an aliquot of the slurry was taken from the flask at atmospheric pressure for the analysis. Soon after that, the flask was back to vacuum-distillation.

B : calculated values based on the concentration of citric acid in the slurry.

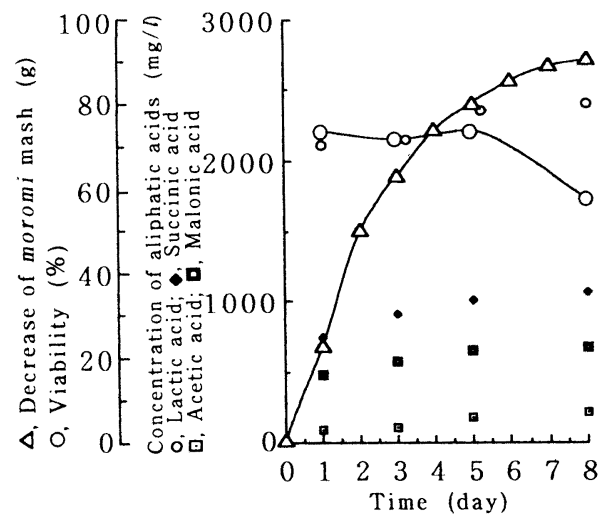

Fig.5 Course of fermentation, viability and aliphatic acids in the moromi mash prepared by the newly developed recycling process ( $k a e$ shi-jikomi) without addition of yeast, rice koji and water.

Post-distillation slurry was derived from distillation of the second-stage moromi mash with $33 \%$ koji ratio $(1,600 \mathrm{~m} \ell)$.
の増加量はそれぞれ $100 〜 200 \mathrm{mg} / \ell$ であった。これ らの有機酸については, 既に報告したように従来法の 二次仕込みで生成されており, 乳酸にいたっては仕込 み 9 日目で $2,000 \mathrm{mg} / \ell$ に達していた ${ }^{2)}$ 。酒精酵母は 発酵期間中に有機酸を生成すると言われていることか $ら^{6)}$, 雑菌污染によるものではなく S 20 E 12 株によ り生成されたものと考えられる。

以上, 減圧蒸留により得た蒸留残液を用いた返し仕 込みでは, 酒母や麴を添加しなくても全く問題なく焼 酎を製造できることがわかった。

\section{4. 返し仕込み日数の製品への影響}

麥步合 $33 \%$ の従来法による二次仕込みを中スケー ル (約 $2 \ell)$ で 8 日間行い, 得られた最終醪 1,600 m を減圧蒸留した。この蒸留残液 $175 \mathrm{~m} \ell$ と蒸米 $138 \mathrm{~g}$ （掛米 $106 \mathrm{~g}$ ）だけを $500 \mathrm{~m} \ell$ 三角フラスコに添加した ものを 4 本調製し, 返し仕込み試験を 8 日間, 10 日間, 12 日間抢よび 15 日間行った。図示しなかったが，4 本の発酵経過は全く変わることなく安定して進行し, 少なくとも10日目に終了することがわかった。9日目， 
11 日目, 13 日目および 16 日目で返し仕込みを終了し， それぞれの醪を分析した。Table 4 に示したように 返し仕込み日数が長くなると生存率は低下するが, 従 来法の二次仕込み終了後のように極端に死滅する2)こ とはなかった。しかし，発酵終了後，早い時期に $\alpha$ アミノ態窒素や硫黄濃度は 10～20\%増加する傾向を 示した。このことから, 従来法の二次仕込み終了時と は異なり死滅した酵母は，速やかに自己消化していく
ものと思われた。生成エタノール濃度は仕込み日数が 長くなるにつれ増加したが，9日目においても $18 \% \mathrm{v} / \mathrm{v}$ を超えていた。

これらの最終醪 $250 \mathrm{~m} \ell$ を約 30 分蒸留して得た製品 の香気成分の分析結果を Table 5 に示した。香気成 分は, 前述したように従来法同様仕込み日数が長くな るほど低下する傾向を示し, 特に酢酸イソアミルと nプロピルアルコールは極端に低下した。しかし, 吟醸

Table 4 Effect of fermentation times on viability and autolysis of the yeast in the moromi mash prepared by the newly developed recycling process (kaeshi-jikomi).

\begin{tabular}{l|c|c|c|c}
\hline \hline Moromi mash & after 8-d & after 10-d & after 12-d & after 15-d \\
\hline Total cell number (cells/ml) & $6.3 \times 10^{8}$ & $6.0 \times 10^{8}$ & $5.3 \times 10^{8}$ & $5.6 \times 10^{8}$ \\
Viable cell number (cells/ml) & $3.7 \times 10^{8}$ & $3.1 \times 10^{8}$ & $2.2 \times 10^{8}$ & $1.1 \times 10^{8}$ \\
Viability (\%) & 58.7 & 51.7 & 41.5 & 19.6 \\
Acid stable $\alpha$-amylase (U/m) & 12.3 & 11.5 & 10.8 & 9.5 \\
Glucoamylase (U/ml) & 3.9 & 3.4 & 3.3 & 3.3 \\
Sulfur compound-S (mg/l) & 311.1 & 340.7 & 370.1 & 359.4 \\
$\alpha$-Amino nitrogen (mg/l) & 843.6 & 899.8 & 964.9 & 1.009 .9 \\
Ethanol concentration (v/v\%) & 18.7 & 19.5 & 20.1 & 20.6 \\
\hline
\end{tabular}

The second-stage moromi mash with $33 \%$ koji ratio was fermented for 8 days. After completion of the fermentation, it was vaccum-distilled, and the slurry was obtained. The kaeshi-jikomi moromi consisting of $175 \mathrm{ml}$ of the slurry and $138 \mathrm{~g}$ of steamed rice in a $500 \mathrm{ml}$ Erlenmeyer flask was fermented for $8,10,12$ or 15 days.

Table 5 Effect of fermentation times on flavor compounds in shochu made by the newly developed recycling process (kaeshi-jikomi).

\begin{tabular}{|c|c|c|c|c|}
\hline Flavor compounds & after 8 -d & after $10-d$ & after $12 \cdot d$ & after $15 \cdot d$ \\
\hline Acetaldehyde & 10.2 & 14.9 & 17.4 & 20.6 \\
\hline Ethyl acetate & 49.6 & 52.6 & 60.2 & 61.3 \\
\hline n-Propyl alcohol & 178.1 & 106.5 & 83.8 & 53.3 \\
\hline Isobutyl alcohol & 192.5 & 185.2 & 175.2 & 111.0 \\
\hline Isoamyl acetate & 8.2 & 6.3 & 2.7 & 1.0 \\
\hline $\begin{array}{l}\text { Active amyl alcohol } \\
\text { Isoamyl alcohol }\end{array}$ & 312.7 & 317.6 & 279.4 & 292.4 \\
\hline$\beta \cdot$ Phenetyl alcohol & 30.7 & 31.4 & 26.5 & 34.1 \\
\hline Ethl n-caprylate & 0.5 & 0.7 & 0.7 & 0.5 \\
\hline$\beta$-Phenetyl acetate & 2.7 & 2.7 & 2.4 & 2.3 \\
\hline Ethyl laurate & 0.1 & 0.1 & 0.3 & 0.1 \\
\hline Ethyl myristate & 0.5 & 0.4 & 0.4 & 0.3 \\
\hline Ethyl linoleate & 0.8 & 0.5 & 0.5 & 0.3 \\
\hline Ethyl oleate & 0.5 & 0.3 & 0.4 & 0.3 \\
\hline Ethyl stearate & 0.1 & 0.1 & 0.1 & N.D. \\
\hline $\begin{array}{l}\text { Acidity } \\
\mathrm{pH}\end{array}$ & $\begin{array}{l}0.6 \\
5.0\end{array}$ & $\begin{array}{l}0.8 \\
4.9 \\
\end{array}$ & $\begin{array}{l}0.8 \\
4.9 \\
\end{array}$ & $\begin{array}{l}0.9 \\
4.6 \\
\end{array}$ \\
\hline
\end{tabular}

After complection of the fermentation shown in Table 4 , the four kinds of moromi mash were vaccum-distilled for shochu production. 
香の一つである酢酸イソアミルは返し仕込み 9 日目の 製品に $8.2 \mathrm{mg} / \ell$ も含まれていた。一方，ガス臭の原 因となるアセトアルデヒドは,やはり従来法同様仕込 み日数が長くなると増加するが, それでも品質が良い とされる米焼酎の值 ${ }^{8}$ よりもむしろ低かった。減圧蒸 留で得られる良い米焼酎の定義から, やはり返し仕込 みにおいても発酵終了醪は直ちに蒸留すべきである。

\section{5. 返し仕込みに使用する蒸留残液の放置時間の 影響}

返し仕込みを実規模で行うことを想定して以下の検 討を行った。球磨地区における醸造場での減圧蒸留最 終温度は約 $45^{\circ} \mathrm{C} に$ 達するので, 蒸留残液の温度もこ の程度と思われる。規模により異なるが, 約 $1,000 \ell$ の蒸留残液を発醉槽（二次仕込み槽）に入れ， $25^{\circ} \mathrm{C}$ 以 下に冷却した後, 蒸米を添加すると仮定すると, 冷却 装置がない場合, 作業性から当然翌日に蒸米を添加す ることになる。この場合, 雑菌污染が眯念されるので, 実験室規模で約 4 時間かけて減圧蒸留した蒸留残液を ナス型フラスコに残したまま 24 時間放置し，その蒸 留残液を用いて返し仕込みによる焼酎製造に関する検 討を行った。まず，24 時間放置している間の生存率 や有機酸の経時変化を調べた。図示しなかったが, 生 菌数は若干増減するものの, 生存率は $35 \%$ とほとん ど変化しなかった。総有機酸濃度は $3,500 〜 3,800$ $\mathrm{mg} / \ell$ と若干増加しているが，酢酸濃度は 206〜229 $\mathrm{mg} / \ell$ とほとんど変化しないこと, 酪酸や吉草酸が検 出されなかったことから, 雑菌による污染はないもの と考えられた ${ }^{6)}$ 。また，放置前後の糖化酵素活性を測 定したが, 耐酸性 $\alpha$-アミラーゼ活性は 21.3 から $22.2 \mathrm{U} / \mathrm{m} \ell$, グルコアミラーゼ活性は 6.4 から $6.1 \mathrm{U} /$ $\mathrm{m} \ell$ と全く活性の低下は見られなかった。そこで，この 24 時間放置した蒸留残液を用いて同様にして返し仕 込み試験を行った。開始当初はやはり粘度が高かった ので，4日目からサンプリングし分析を行った。 Fig.6に示したように, 今回の生存率は今まで実験室 規模で行ってきたものよりも高かった。また，総有機 酸濃度は 6 日目に若干増加しているが, その後減少し, 最終的にはほとんど変化していなかった。糖化活性に ついて返し仕込み日数を検討した時の值（Table 4 参照）と比較すると，9日目における耐酸性 $\alpha^{-}$アアミ ラーゼ活性は約 30\%低下しているが，グルコアミラ 一ゼ活性は約 2 倍高かった。この差は, 放置前後の両 酵素活性が全く変化していなかったことから，実施し た仕込み試験により若干変化するものと思われた。

\section{要 約}

官能試験結果および生存能から選抜した焼酎酵母 S $20 \mathrm{E} 12$ 株を用いて実験室規模で返し仕込みによる焼

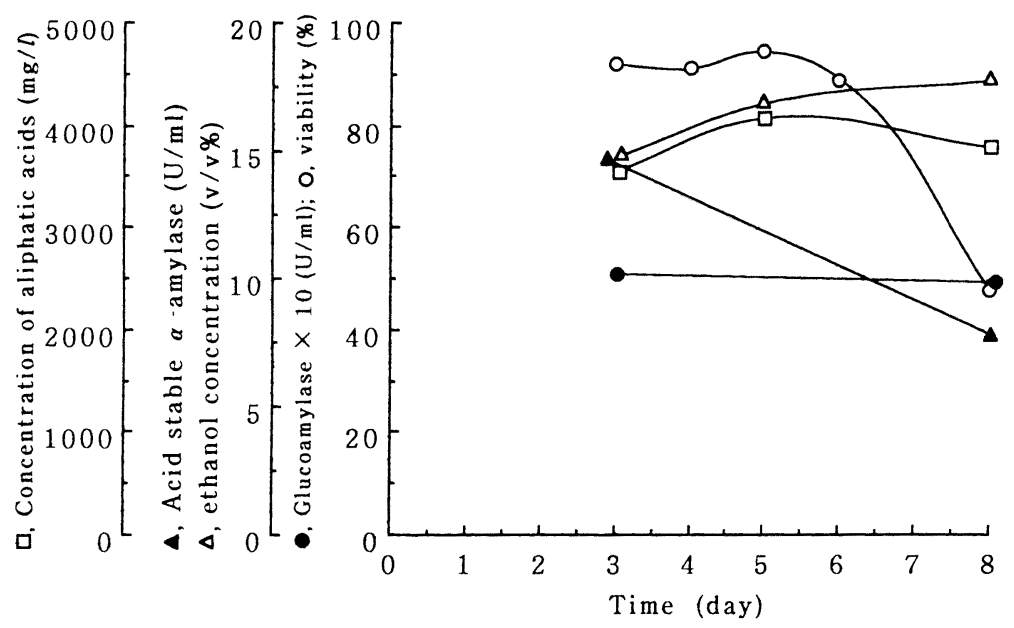

Fig. 6 Course of fermentation, viability, aliphatic acid concentration and saccharifying enzyme activities in the moromi mash in the newly developed recycling process (kaeshijikomi) using post-distillation slurry left in a room temperature for 24 hours. 
酎製造に関する研究を行った。得られた結果を以下に 要約する。

（1）従来仕込み条件の返し仕込みへの影響をまず 検討した。その結果, 従来法による二次仕込みでは発 酵終了後, 酵母は速やかに死滅することから, 発酵終 了酫は直ちに蒸留される方が酒質面等から好ましいこ とがわかった。また，返し仕込みの発酵速度および開 始時の粘度から，従来法の麴歩合を $30 \%$ 以上とした。

（2）従来法（麴歩合 $33 \% ）$ の二次 9 日目の型を - $63 \mathrm{cmHg}, 45^{\circ} \mathrm{C}$ 条件で約 4 時間かけて減圧蒸留 した。蒸留前後に打ける糖化酵母活性は, むしろ増加 した。また，この間酵母は約 $35 \%$ 死隇したが，蒸留 残液中に酵母はなお $4.7 \times 10^{7}$ cells/ml生存していた。

（3）蒸留残液に酒母や麴を添加することなく，た だ蒸米だけを加え返し仕込み試験を行った。発酵は雑 菌污染することなく，9日目にはすでに終了していた。 発酵日数の異なる醪を蒸留し, 得られた製品の香気成 分を分析した結果, 発酵日数が長くなる程, 酢酸イソ アミルやn-プロピルアルコールは減少し, 逆にアセ トアルデヒドが増加した。従って, 酒質面から従来法 同様, 発酵終了後直ちに醪を蒸留すべきであることが わかった。

（4）蒸留残液を室内で 1 日放置しても污染の恐れ もなく，また生菌数や糖化活性も全く変化しなかった。 この蒸留残液を用いて返し仕込みを行ったところ, 発
酵や酒質への影響は全く見られなかった。

本研究の遂行にあたりご指導, ご助言を賜りました 熊本国税局鑑定官室長嶋㠃孝行氏，前主任鑑定官白上 公久氏および鑑定官室の諸氏に厚く御礼申し上げます。 また, 本研究に協力された学生吉田めぐみさんおよび 鶴田恵三君に心から感謝いたします。なお，本研究は 日本酒造組合と球磨焼酎酒造組合, 熊本大学工学部物 質生命化学科との共同研究で実施したものである。

\section{文献}

1）朝日新聞：1996 年 10 月 4 日付け記事

2）中川優，森村茂，木田建次：醸協，92，（9） 651 (1997)

3）三枝維彦，山上昌上，岡村成通，原田倫夫：生 物工学, 73, 105 (1995)

4) Y. Yoshino, S. Hayashida, J. Ferment. Technol., 56, 289 (1978)

5）清酒酵母の研究：清酒酵母研究会 (編集)，116 (1992)

6）西谷尚道：醸協，75，（8）641（1980）

7）西谷尚道：醸協，75，(12）944（1980）

8）西谷尚道，大内弘造，飯村穣，秋山裕一：醸造 試験場報告，154，15（1982）

9）若井芳則：醸協，83，（9）579（1988） 